This item was submitted to Loughborough's Research Repository by the author.

Items in Figshare are protected by copyright, with all rights reserved, unless otherwise indicated.

\title{
Memory, post-socialism and the media: nostalgia and beyond
}

PLEASE CITE THE PUBLISHED VERSION

http://dx.doi.org/10.1177/1367549416682260

PUBLISHER

SAGE $\odot$ The Author

\section{VERSION}

AM (Accepted Manuscript)

\section{PUBLISHER STATEMENT}

This work is made available according to the conditions of the Creative Commons Attribution-NonCommercialNoDerivatives 4.0 International (CC BY-NC-ND 4.0) licence. Full details of this licence are available at: https://creativecommons.org/licenses/by-nc-nd/4.0/

\section{LICENCE}

CC BY-NC-ND 4.0

\section{REPOSITORY RECORD}

Mihelj, Sabina. 2019. "Memory, Post-socialism and the Media: Nostalgia and Beyond". figshare. https://hdl.handle.net/2134/22974. 
This is a pre-print version of the manuscript as accepted for publication in the European Journal of Cultural Studies 20(3), forthcoming June 2017

\title{
Memory, Post-socialism and the Media: Nostalgia and Beyond
}

\author{
Sabina Mihelj
}

\begin{abstract}
While research on the mediation of post-socialist memory has gained momentum in recent years, the field remains fragmented and limited to small-scale case studies, with little attempt to develop a more general reflection on the nature of the processes investigated. Engagement with the wider literature on the mediatisation of memory has been limited as well, with research typically applying established conceptual frameworks rather than using post-socialist materials to generate new theoretical insights. Given the state of the field, this article has a double aim. First, it offers a critical review of the main trends in existing research, focussing on four key issues: the fascination with nostalgic modes of remembering, the dominance of national frames of analysis, the lack of research on the mediation of personal and vernacular remembering, and the privileging of descriptive over explanatory modes of analysis. Second, the article outlines a new agenda for the field, and proposes three main research trajectories. The first pays attention to how mediated memories at local and national levels interact with transnational processes of remembering the Cold War, the second focusses on to the intersections between personal and public modes of mediated remembering, and the last moves the discussion from description to explanation, using comparative approaches to advance explanations of different modes of mediated postsocialist memories.
\end{abstract}

Keywords: memory, media, post-socialism, nostalgia, television, transnational memory

The demise of state socialism in Eastern Europe triggered a profound restructuring of individual and collective relationships with the socialist past. Released from the straightjacket of Cold War politics, memories of the Second World War, the communist takeover and the decades of life under communist rule provided a rich resource for politically driven mythmaking across the political spectrum, as well as for creative engagements with the past in the visual arts and museums (e.g., Bernhard and Kubik 2014, Boym 2001, Sarkisova and Apor 2008, Tileaga 2012, Todorova and Gille 2010). Narratives of the socialist past also became important at vernacular and everyday level, and served as vehicles for making sense of the post-socialist transformation and for orienting one's own sense of identity and belonging (e.g., Berdahl 2010, Mark 2010, Mihelj 2014, Rabikowska 2013). The rich and growing body of scholarly work on post-socialist memory has by now provided important insights into the varied layers and processes of memory formation in the region, ranging from public to vernacular and personal memories, as well as helped further our understanding of mnemonic processes more generally, elucidating the ways in which they are affected by rapid political, economic and social changes.

In recent years, the role of the media in shaping post-socialist memories has also begun to attract attention. One of the notable traits of existing research in this area is its preference for small-scale case studies focused on a single medium and situated in specific national locales (for an exception see Volčič 2007). So far film has received the most concerted attention, with studies typically privileging the analysis of cinematic texts over the analysis of audience reception and the political and economic uses of mediated representations of the past (Bardan 
2012, Godeano-Kenworthy 2011, Kapczynski 2007, contributions on film in Sarkisova and Apor 2008, Norris 2012). In contrast, research concerned with the mnemonic functions of television is more sociologically minded, pays less attention to televisual representations themselves, but regularly reaches beyond the analysis of television programmes to investigate how they interact with shifts in the wider political, cultural or economic context (Khinkulova 2012, Imre 2013) or how they enter processes of vernacular and autobiographical memory formation (Bloch 2013, Lepp and Pantti 2013, Reifová 2009, Reifová et al. 2012, SorescuMarinković 2012). Studies of digital memories (e.g., Mikula 2003, Kaprans 2015, Rutten et al. 2013), radio (e.g., Kaun and Stiernstedt 2012) and photography (e.g., Petrović 2009, Sarkisova and Shevchenko 2014) started emerging as well.

While elucidating the embeddedness of mediated memory in specific locales, the preference for local, small-scale research has also meant that discussion has remained fragmented, with little attempt to develop a more general reflection on the nature of mediated memory in the post-socialist context. Engagement with wider debates on the role of the media in mnemonic processes has been limited as well, with research typically applying established conceptual frameworks rather than using post-socialist materials to contribute new insights into the mediation of memory more generally. Given the state of the field, this article, along with the themed issue it forms part of, has a double aim. The first aim is to offer a critical review of main trends in existing research, focussing on four key issues: the fascination with nostalgic modes of remembering, the dominance of national frames of analysis, the lack of research on the mediation of personal or vernacular remembering, and the privileging of descriptive over explanatory modes of analysis. Due to the volume of research in this area, it is impossible to offer an exhaustive review and include references to all relevant literature. Instead, only a selection of relevant examples is discussed. In making the selection, preference was given to literature that focuses comprehensively on mediated remembering rather than discussing media alongside other aspects of post-socialist memory. We also sought to include examples that cover different post-socialist locales, and stem from different disciplinary backgrounds.

The second aim of this article is to outline a new research agenda for the field, and explain how the remaining contributions to the themed issue help advance this agenda. Three main avenues for future research are proposed. The first one consists of tracing the mediation of post-socialist memory across different spatial scales, paying particular attention to how mediated memories at local and national levels interact with transnational processes of remembering, and with the uneven power relationships that underpin them. The acknowledgment of the transnational dynamics of post-socialist memory is largely absent in existing research, yet crucial given the subordinated role of post-socialist memory agents in global memories of the Cold War. The second avenue involves capturing the diverse social realms of mediated memories, focussing not only on the involvement of the media in shaping and filtering public memories of state socialism but also on how the diverse types of home and mass media become embedded in personal recollections of the past. The end of the Cold War was a profoundly unsettling process accompanied by rapid political, social and economic changes, yet we still know relatively little about the involvement of the media in negotiating this break, especially in the context of vernacular and autobiographical memories. The third avenue proposed in the article demands a shift from description to explanation. Twenty-six years since the fall of the Berlin Wall, we should be in a position to investigate the mediation of post-socialist remembering in a more ambitious and rigorous manner, and apply comparative approaches designed to explain both change over time and variation across different social and political contexts. 
A final clarification is in order before proceeding. While the general arguments developed here apply to processes of mediated post-socialist memories more generally, the empirical focus of the themed issue is on television. Ther are several reasons for this. First, socialist television programmes remained hugely popular well beyond 1989, constitute a staple of television programming in several post-socialist countries to this day, and are continuously re-packaged and re-distributed across a variety of media platforms; as a result, television forms a central ingredient of mediated post-socialist remembering (e.g., Imre 2016: 167-171, Khinkulova 2012, Reifová 2009, Volčič 2007). Second, much of the socialist period coincided with the rise of television as a key source of information, which means that television functioned as a key repository and resource for memory formation. At the same time, the inherent qualities of television turned the medium into a particularly powerful vehicle of memory. Thanks to its ability establish a live, visually and aurally palpable connection with the unfolding present, television coverage of major events often gave rise to veritable 'electronic monuments' that offered an enduring point of reference for recollections of the past (cf. Dayan and Katz 1992). Furthermore, the medium's close ties with the routines of everyday life and its capacity to forge intimate bonds between viewers and TV personalities also provided the basis for particularly compelling modes of mediated engagement with the past (cf. Creeber 2001). Last but not least, a focus on a single medium provides a level of coherence that enables the reader to draw more general conclusions about the specificities of televisual mediatisation of memory.

\section{Nostalgia and Beyond}

Even a cursory look at the existing body of work on post-socialist memory instantly reveals a fascination with nostalgia, a term used loosely to refer to a variety of practices and beliefs that involve a sentimental relationship with the past, accompanied by feelings of loss and longing (for a selection of literature on the topic see Boym 2001, Nadkarni and Shevchenko 2004, Boyer 2006, Berdahl 2010, Todorova and Gille 2010, Velikonja 2009). From the craze for socialist-era consumer products to happy memories of everyday life under communist rule, post-socialist nostalgia has attracted attention among scholars from a variety of disciplinary backgrounds, from history to anthropology and sociology. Taken together, this interdisciplinary body of work points to a range of factors responsible for the rise of nostalgic attitudes to the past, including politically motivated readings of recent history that downplay the hardships of life under communist rule, commercially motivated 'repackaging' of symbols and products from the bygone era, as well as grass-root reactions to the hasty rejection of all things socialist after 1989 and to the growing economic uncertainty and social disparities brought by economic liberalization. These competing interpretations of nostalgia resonate also in the bulk of existing research on post-socialist media and memory, which is similarly attracted to nostalgic engagements with the past (e.g., Godeano-Kenworthy 2011, Kapczynski 2007, Volčič 2007, Daković 2008, Pobłocki 2008, Reifová et al. 2012, Khinkulova 2012, Imre 2013, Imre 2016: 155-172).

If one were to judge solely by available research, it would be tempting to conclude that postsocialist nostalgia constitutes the most common relationship with the past in Eastern Europe. Indeed, one is left with the impression that post-socialist citizens have undergone a radical reversal of their relationship with time, suddenly dropping their future-oriented, revolutionary sense of time and transforming themselves into past-oriented beings filled with a sense of loss or even longing for the bygone era. Yet, as soon as we consider the empirical basis of research on nostalgia, it becomes apparent that this sense of pervasiveness may to some extent be simply a product of scholarly investment in the topic. By and large, research on 
post-socialist nostalgia is typically based on small-scale research that intentionally zooms in on nostalgic practices and beliefs rather than scrutinising them in the context of a diverse set of possible relationships with the past. In the field of media research, for instance, it is common for studies to focus on one or two expressly nostalgic films such as Wolfgang Becker’s Good Bye Lenin! (2003) (e.g., Godeano-Kenworthy 2011, Kapczynski 2007), or ascribe the label of nostalgia to instances of re-mediation involving socialist-era films, television programmes or popular music (e.g., Volčič 2007, Khinkulova 2012). While such examples can offer valuable insights into the logic of mediated nostalgia, they are not sufficient to establish the relative role of nostalgic practices vis-à-vis other relationships with the past, such as for instance trauma or shame, or to identify the reasons that lead to the ebbs and flows of nostalgia over time and space. In this context it is rather telling that the more broadly based empirical studies of post-socialist memory, such as James Mark’s (2010) examination of vernacular memory based on 118 interviews conducted across three countries, or the twelve-country comparison of public commemorations of 1989 led by Bernhard and Kubik (2014), devote relatively little space to nostalgia. In Bernhard and Kubik's analysis, for instance, Bulgaria emerges as the only country in which the twentieth anniversary of 1989 was marked by considerable nostalgia for state socialism. This suggests that the study of mediated nostalgia would profit from similar analytical approaches, designed to trace its relative prominence through time or across different political and cultural contexts. While a cross-national comparative endeavour of this kind is beyond the scope of this themed issue, two of the contributions, written by Ekaterina Kalinina and Simon Huxtable, pay attention to transformations over a longer span of time, and thereby demonstrate the usefulness of historical comparisons in understanding post-socialist memory.

Another drawback of debates about post-socialist nostalgia lies in the sheer diversity of attitudes and uses of the past captured by the term. For Volčič, the production and circulation of nostalgic representations of the state socialist past in post-Yugoslav states is stimulated largely by the logic of capitalist economy, which 'warps the past in order to commodify it' and thereby precludes any deeper engagement with historical reality (2007: 35). In his analysis of Polish post-socialist cinematography, Pobłocki (2008) likewise links the boom of nostalgia with the economic transformation of Poland after 1989, but also considers its links with political shifts in the country over several decades. He argues that the phenomenon initially appeared as a grass-roots reaction to the uncompromising anti-communism of the late 1980s and the early 1990s, and subsided with the political changes from 2002 onward which brought changes in the politics of the communist past and an outright denunciation of nostalgic practices. In a somewhat similar fashion, Khinkulova (2012) draws a broad-brush overview of the changing politics of nostalgia on television in post-Soviet Ukraine and Russia, linking it to political changes as well as to the shifting media-politics relationships and attitudes to the West in the two countries. In Putin's Russia, argues Khinkulova, Soviet television culture became a marker of cultural superiority vis-a-vis the purportedly low quality of Western imports, which stimulated a growth of nostalgic programmes and rebroadcasting of Soviet-era content. In contrast, the pro-European orientation of Ukrainian politics in the same period led television to turn away from the Soviet past and produce new cultural output drawing on formats imported from the West. Yet, as Imre's (2013) analysis of Hungarian materials demonstrate, mediated nostalgia cannot be easily mapped on to traditional political divisions, nor does it necessarily coincide with shifting attitudes to the West or the EU. For instance, despite its staunchly anti-communist credentials, the Hungarian right-wing government FIDESZ actually promoted the revival of socialist content on television, demonstrating that as far as the media are concerned nostalgic attitudes are politically rather promiscuous. 
Analysts of nostalgia often seek to capture the diversity of nostalgia and its uses by proposing different typologies. Particularly widely cited is Boym's (2001) distinction between restorative nostalgia, motivated by a wish to reconstruct the past in a transhistoric fashion, and reflective nostalgia, which allows for doubt, irony and critical reflection. Along with many other attempts to capture the diversity of post-socialist nostalgia, Boym's distinction centres on different temporal orientations of the phenomenon. Here, the intention is to demonstrate that nostalgic practices and beliefs are not necessarily oriented solely towards the past, but can also act as a means of talking about the present and the future. Other typologies of nostalgia acknowledge not only its diverse temporal orientations, but also its different forms of expression and different economic and political uses. This is the case in Maya Nadkarni and Olga Shevchenko's (2004) typology, which distinguishes five different types of post-socialist nostalgia, ranging from the commodification of the official symbols of communist ideology such as red banners or portraits of communist leaders to a more diffuse, 'postmodern' fascination with a generalised sense of 'retro' and socialist style that is not attached to any specific local history. Zala Volčič’s (2007) typology follows a similar logic, and distinguishes three modes of nostalgia at work in post-Yugoslav media and culture: revisionist nostalgia, which uses the idealised memory of Yugoslav brotherhood and unity to call for a renewal of belonging to a shared (post-)Yugoslav community in the present; aesthetic nostalgia, which seeks to preserve the authentic Yugoslav past, untarnished by political aims or commercial interests; and escapist nostalgia, which exploits the longing for an idyllic Yugoslav past for commercial gain. More recently, Aniko Imre (2013) offered another take on the diversity of nostalgia, this time by identifying different television genres that have been subjected to nostalgic uses or interpretations, ranging from entertainment shows featuring socialist-era celebrities to commercials and popular music.

While such typologies go a considerable way towards unpacking the heterogeneity of nostalgic practices and beliefs in the post-socialist world, they fall short of offering analytical instruments that have purchase across different political and cultural realms in which nostalgia appears. To start with, these typologies often capture only one dimension of variation (e.g. temporal orientations). Alternatively, when different dimensions of variation are acknowledged, they are conflated in a single typology, assuming for instance that one type of political orientation (such as left-wing politics) has an elective affinity with one type of temporal orientation to the past (such as restorative nostalgia). Furthermore, most of these typologies are oblivious to the polysemic nature of nostalgia. As Nadkarni and Shevchenko (2004: 505-506) point out in their critical assessment of the field of post-socialist nostalgia studies, nostalgic practices are inherently polysemic, and can articulate a range of different attitudes to the past. Arguably, media and communication scholars are particularly wellequipped to attend to the multiple meanings of nostalgia, and their different articulations in specific contexts of reception. Yet intriguingly, audience-centred approaches to post-socialist nostalgia remain rare, with the studies conducted by Irena Reifová and colleagues (Reifová 2009, Reifová et al. 2012) constituting rare examples of full-blown audience reception research in the field available in English. To capture the diversity of beliefs and practices labelled nostalgic we therefore need more precise ways of distinguish analytically between different types of nostalgia, along several planes - temporal orientations, forms of expression, political uses, and economic motivations - without conflating them in a single typology. In addition, we also need to pay closer attention to the communicative nature of nostalgia, and acknowledge the different interpretations and uses of the same nostalgic object at different points in the process of its production, dissemination and reception. Such sensitivity to the polysemic character of nostalgia may also mean accepting that practices, beliefs or objects 
that we initially recognise as nostalgic are not understood as such by people who engage with them. This route is pursued in Alice Bardan's contribution to this themed issue, which seeks to explain the continued popularity of socialist television programmes in contemporary Romania, as well as in Huxtable's analysis of popular recollections of late Soviet television psychics. Both contributions show that vernacular memories of socialist media cannot be reduced to nostalgia, and instead reveal a more nuanced and polysemic relationship with the state socialist past.

\section{From post-socialist memory to transnational memories of the Cold War}

Post-socialist memories generated in former socialist countries do not exist in isolation, but form part of broader, transnational circuits of memories of the Cold War. Images of the toppling of Berlin Wall, along with other icons of Cold War memory, have a global resonance akin to that evoked by other major historical turning points and traumatic events that disrupt the regular flow of social time. According to Levy and Sznaider (2002: 97), the end of the Cold War facilitated a proliferation of such transnational memories; as the bi-polar framework of the Cold War vanished, the foundations of international cooperation had to be revised, which also opened doors for the growing globalisation of memory. The end of the Cold War was of course not the only trigger of this process. Thanks to the combined effects of transnational migration and tourism, the advent of global ecological and terrorist threats, the rise of global media conglomerates and the growing political and economic interdependence of the modern world, global concerns are increasingly becoming entwined with local, everyday experiences. In this context, argued Levy and Sznaider (2002: 88-89), memories can no longer be confined solely to national or ethnic communities but exist on several planes simultaneously. As a result, a new form of 'cosmopolitan memory' (ibid., see also Misztal 2010, Tzanelli 2011) has emerged alongside nationally bounded memories, one which is shared not only by individuals and communities who directly experienced a particular event or period, but also by wider communities with little or no personal connection to the historical realities remembered.

Given the undisputed role of transnational flows of imagery and narratives in the iconic events of the Cold War, and the growing body of work that adopts a global, transnational approach to this global conflict (e.g., Bracke and Mark 2015, Chari and Verdery 2009, Kwon 2010), it is surprising how little has been done to trace the involvement of the media in the formation of transnational memories of the Cold War era. With the exception of some of the recent work on digital memory wars in post-socialist Poland, Ukraine, Russia and the Baltics (e.g., Rutten et al. 2013, Kaprans 2015) the vast majority of research remains national in focus. The rare studies that venture into examining the mediation of Cold War memories elsewhere in the world (e.g. Li and Lee 2013) tend to be limited to single states. The only major exception to this trend is Julia Sonnevend's study of the making of the fall of the Berlin Wall as a global iconic event, which relies on the analysis of media sources from the US and Germany (including papers formerly published in the GDR) as well as some Soviet media materials.

Of course, the existence of transnational memory does not mean that the end of the Cold War has given rise to a harmonious, internally homogeneous process of remembering devoid of conflicts. As Pawas Bisht (2013: 14) notes, the overemphasis on the transnational, globally connected nature of memory can run the risk of under-emphasizing 'the limits, contestations and inequalities' that criss-cross transnational memory processes. To put it differently, rather than mnemonic contestation disappearing altogether and giving way to a shared remembering 
at transnational level, the mnemonic battles themselves have become increasingly transnational in scope, requiring a multi-level analysis that acknowledges the mutual imbrication of local, national and transnational processes of remembering, as well as the uneven power relationships that underpin them.

What does this mean in the context of post-socialist memory, and its mediation, in particular? To start with, it is important to note that what one remembers about socialism is shaped by the dynamics and outcomes of the Cold War, and by our own vantage point in this context. Through the eyes of political elites and commentators in the West, the fall of the Berlin Wall is typically remembered in positive terms, as a turning point that symbolises the demise of Communism and the simultaneous victory of liberal democracy and capitalist economy. Yet this is far from being a shared memory. As Bernhard and Kubik (2014) demonstrate in their comparative study of commemorative events marking the twentieth anniversary of the end of the Cold War, the memories in former socialist countries are often profoundly conflicted. As a result, attempts to create a common European memory often involve difficult negotiations in which eastern Europeans' attitudes to the past are evaluated from the point of view of dominant western narratives. This has become particularly evident in post-unification Germany, where memories of historical events and developments in the western part of the country are used as a frame for interpreting and evaluating the history of its eastern counterpart (von der Goltz 2013). Likewise, among European Union elites, memories of communist rule in the eastern part of the continent are often problematized, leading to various pressures on eastern European countries to remember their past in appropriate ways, paying due attention to the oppressive elements of communism as well as to their own involvement in the Holocaust (Mälksoo 2014).

The prominence of nostalgia in debates about post-socialist memory can itself be seen as a product of such transnational politics of remembering and forgetting. As Nadkarni and Shevchenko (2004: 297) argue, Western media's fascination with post-socialist nostalgia can be interpreted as an expression of the West's own longing for a period when the Western way of life presumably functioned as an undisputable ideal for the socialist east. This longing, they continue, arises in the context when the new Other of the West, Islamic fundamentalism, shows little sign of a comparable interest for Western culture and consumer products. In a related argument, Dominic Boyer (2010: 22) interprets the close association of nostalgia and post-socialism as 'vital for Western European socio-political imagination', and as part of the practice of temporal displacement that shifts Eastern Europe temporally 'into the imagined margins of the urban, industrial, and scientific centres of Western European modernity'. In this sense, then, the pervasiveness of the discourse about nostalgia can be seen as a local manifestation of Orientalist discourse (Said 1978) that sees the East as backward, steeped in the past, or otherwise alien to the Western self.

The diversity of approaches adopted in contributions to this themed issue seeks to capture some of the ways in which we can make our study of post-socialist memory more open to transnational perspectives. Two key strategies can be highlighted, both premised on uncoupling the study of post-socialist memory from the study of post-socialist societies. In the first approach, this is achieved by focusing the analysis on social contexts that have not experienced communist rule, or by examining the formation of memory at a global level. As Mari Pajala's study of televised memories of socialism in Finland demonstrates, refocusing the analysis on countries without a history of communist rule leads to particularly fruitful results when it is applied to countries that had an ambiguous position in the East-West confrontation. The mediated memories that emerge from Pajala's analysis display features 
strikingly similar to those that are found in post-socialist countries further east, combining critical revisions of the politics of Finnish-Soviet friendship with nostalgia for Soviet popular culture. Lars Lundgren and Christine Evans, on the other hand, adopt a global comparative focus, investigating the historical production of two memorable media events: the return on the Soviet cosmonaut Yuri Gagarin to Moscow after orbiting the earth in 1961 and the Our World broadcast in 1967. Although the Gagarin landing occurred earlier and was in some ways more successful, it is the latter event that is more commonly remembered as a landmark occasion in global television history. As Lundgren and Evans argue, the position of the two events in the remembered history of global television is a result of the global power dynamics that privileges accomplishments spearheaded by Western powers over those initiated in the state socialist east. This dynamics is rooted in the longer history of uneven power relationships that underpinned transnational television production from its very inception.

In the second approach, the analysis remains empirically limited to nationally bounded cases from the post-socialist world, but incorporates an awareness of transnational similarities and differences. For instance, Alice Bardan's analysis of the popularity of socialist-era television programmes is empirically limited to post-socialist Romania, but examines the phenomenon in light of theories and arguments about mediated nostalgia based on examples from elsewhere in the world. By doing so, she draws attention to the fact that post-socialist nostalgia forms part of a wider, transnational nostalgia boom that is not confined to the postsocialist world.

\section{Between public and personal memories}

Apart from examining the mediation of post-socialist memories across different spatial planes, this themed issue also seeks to capture the different social realms of remembering. In line with this, contributions examine both the involvement of television in producing, filtering and circulating public memories across large-scale communities (foregrounded in Lundgren and Evans, Pajala, Kalinina), and the ways in which televised representations of the past become intertwined with the articulation of personal or autobiographical memories (highlighted in Szostak, Bardan, Huxtable). As noted earlier, research on the mediation of vernacular and autobiographical memories of state socialism is particularly scarce, and this themed issue seeks to address this omission. Yet, while using the distinction between public and personal memories, the contributors to this issue do not want to suggest that the two planes of remembering are neatly separated. This is a common fallacy in many existing attempts to distinguish between the different social planes of remembering, including John Bodnar's (1992) distinction between official and vernacular memories, and the conceptual pair of cultural and communicative memory proposed by Jan Assman and John Czaplicka (1995). Consider, for instance, the status of socialist-era family photographs, such as those examined by Oksana Sarkisova and Olga Shevchenko (2014). While they originate in a space that is profoundly personal, they are never intended purely for individual consumption, but are used to mark, remember and communicate significant moments in relation to intimate others, family members, and friends. Not only that, family photographs can also be interpreted with reference to wider mnemonic communities and even framed by historical milestones shared by large-scale national communities, particularly so if they become part of museum exhibitions or are shared via social media. As such, memories triggered by family photographs are 'never truly private [...] they contain multiple possible references to significant historical events and exist at the intersection between communicative and cultural memory' (p. 153). To capture the ambiguous social location of mediated personal memories, José van Dijk (2004: 263) coined the term 'personal cultural memory', which she uses to 
denote 'cultural acts and products of remembering in which individuals engage to make sense of their lives in relation to the lives of others and to their cultural context, situating themselves in time and space'. Conceived in this way, the concept of personal cultural memory neatly captures the porous boundary between personal and public spaces of remembering, and reminds us that even the most intimate memories we capture in a mediated form are constituted in relation to others, and thereby in some sense public.

Because of being tied to mediated memories generated by means of 'home media' such as photographs, home videos or tape recordings, van Dijk's concept covers only one side of the process by which mediated memories transverse the boundary between the private and the public. The other side comprises the process by which publicly circulated memories embedded in genres such as war films, popular songs or mass mediated photographs become part of our personal relationship with the past. Due to the empirical focus on television, this aspect of mediated remembering is of particular relevance to contributions published in this themed issue. Arguably, television clips have become a key means through which the socialist past is portrayed, and play a central part in iconic events associated with this historical era. In what ways do such memories, circulated among large-scale collectives at national or even transnational levels, become intertwined with an individual's first-hand recollections of past experiences, as well as with second-hand accounts gained from proximate others such relatives or friends? In Paul Frosh's (2006) analysis, testimonies about the past brought to us via electronic media demand an imaginative engagement on the side of the audience, which is invited to imaginatively recreate the past of others. Likewise, Michael Pickering and Emily Keightley (2012: 107-108) propose to think of this process in terms of mnemonic imagination, which is mobilised to 'interpret and assimilate the experiences of both proximate and distant others', and thereby provide us with an emphatic relationship with other people's pasts that allows us 'to move through time together'. Mari Pajala's contribution to this volume takes these arguments in a new direction by noting diverse modes of relating to the past embedded in different television genres. Analysing televisual representations or Finnish-Soviet friendship, she points out that television offers an anchor for an experiential rather than cognitive relationship with the past, inviting audiences to not only recall and understand, but actively experience and imaginatively relive life in the past.

Both of these dimensions of media's involvement with memory, however, tend to concentrate on the media as vehicles of memory rather than as an object of remembering in their own right. From the mundane encounters with the media in the course of our daily lives to the more monumental and memorable participation in media events, the means of communication have become a fundamental part of our experience, and as such form part of what we remember about ourselves. For instance, in an early study of the different ways in which people remember television Jérôme Bourdon (2003) distinguishes four key modalities, ranging from memories of our routines and habits of watching television ('wallpaper memories') to memories of real life encounters with the world of media, such as for instance own participation in television programmes ('close encounters'). More recently, Amy Holdsworth (2011: 24) has argued for the importance of acknowledging the sensual nature of memories of television, especially in relation to memories of everyday life in which television forms part of 'a network of senses and impressions that constitute the experience of living within domestic space and within a particular society'. Such memories of life with the media also arise spontaneously in the course of our everyday life, for instance when watching re-broadcasts of old television shows that formed part of our daily routines in the past, when hearing a popular song we grew up with, or when chancing on an old music video clip on YouTube. In such Proustian moments, the media serve not as vehicles of images of the past 
as experienced by distant others, but invite us to engage with memories of our own 'distant selves', and incorporate them into a narrative of who we are today.

It is this mediated engagement with our distant selves that is at the forefront of contributions to this themed issue that engage with personal dimensions of remembering. These contributions help us unpack the ways in which ordinary citizens negotiate their past relationship with state socialism, and how they use the media to construct a sense of a coherent self despite processes of change. At first sight, examining one's memories of life with the media may seem of marginal importance to the broader project of understanding the formation of post-socialist memory. Yet, we should keep in mind that the mass media played a central role in establishing a link between the public goals of the communist project and the private lives of citizens. Especially television seemed to offer an unprecedentedly effective way of propagating the communist agenda, bringing the revolutionary project alive using a variety of audio-visual means and genres, and doing so in the realm of everyday life. Talking about one's life with television thus necessarily involves talking about one's personal engagement with the communist project, not only in the sense of one's formal dealings with the Party but in the form of more diffuse, everyday encounters with communist narratives and ideals, embedded in daily news and popular entertainment. Arguably, the vast majority of former state socialist citizens - all those not actively involved with the regime as either supporters of victims - can extricate themselves from the burden of the past by emphasizing their largely 'privatized' existence. In contrast, memories of state socialist media force individuals to address their own involvement with the now discredited social and political system, from within the realm of their own personal and domestic lives.

Memories of one's past engagement with state socialist media are of course filtered through the lens of present-day narratives about the state socialist past. As James Mark (2010: xxvii) points out in relation to materials from Central-Eastern Europe, the demise of communist rule saw the appearance of 'a new set of political and cultural values determining what could and could not be said', linked to democracy and nationalism. Cultural values linked to democracy also strongly underpin vernacular memories of state socialist media examined in this themed issue and elsewhere (e.g. Reifová et al. 2012), and are most clearly visible in the framing of socialist-era television as 'propaganda' as discussed by Sylwia Szostak. Yet, if awareness of propagandistic aspects of state socialist programming is so widespread, how is one to explain the continued appeal of these programmes? At least two related explanations emerge from this themed issue. One is the memory of one's own enjoyment of such programmes as entertainment, which formed an integral part of one's leisure, friendships, and family routines (Szostak and Bardan, this issue) - and, indeed, also the enjoyment that comes through remembering itself. The other is the memory of one's intimate, emotional connections with the world on screen and its characters, and a sense of familiarity and belonging derived from re-watching them (Bardan, this issue).

The importance of memories of one's own pleasurable engagements with state socialist media - despite their role as ideological tools - also brings us to the importance of past experiences in inflecting post-socialist remembering. While the role of present-day debates about communist rule is clearly important, they do not constitute the only frame that affects post-socialist vernacular memories. This is most clearly shown in Szostak's contribution, which demonstrates that present-day narratives of state socialist media in Poland are intertwined with recollections of one's own experiences. As these experiences differ generationally, the resulting narratives also differ along generational lines. These patterns show that past experiences offer a powerful anchor of continuity that sets limits on 
subsequent reinterpretations of the past. Rather than shaped entirely by the political, economic or cultural exigencies of the present, the mediation of memories is also affected by layers of past experiences and memories, which limit the extent to which the dissemination of revisionist memories of the socialist past can strike a genuine cord with audiences.

\section{Towards explanations}

In traversing the different spatial and social planes of post-socialist memory and media, the contributions to this themed issue map out a variety of factors that can helps us understand not only how, but also why the mediation of post-socialist memory occurs in the way it does. By way of conclusion, it is useful to highlight these different factors in a more systematic manner, moving from transnational to national and individual planes. To start with, Lundgren and Evans bring into view the global power dynamics that underpins post-socialist memoryformation, and the shifting geographies of centres of media power east and west of the former Iron Curtain. To explain the mediation of post-socialist memory we therefore need to be mindful of how these memories fit into the transnational circulation of Cold War memories, and understand that the shape of mediated mnemonic landscapes in former socialist countries is influenced by factors such as the political and juridical regulation of memory at panEuropean and global level. At the same time, we need to avoid assuming that these transnational spaces of remembering can be neatly mapped on to the East-West divide. As Mari Pajala’s investigation of Finnish materials shows, 'Western' media memories of socialism can sometimes display remarkable similarities with mediated mnemonic patterns found in former socialist countries.

In more general terms, the global resonances of post-socialist nostalgia - while frequently acknowledged in existing work - also need more concerted attention. For instance, the fast growing body of literature on mediated nostalgia beyond post-socialist Eastern Europe (e.g. Dwyer 2014, Lizardi 2014, Niemeyer 2014) provides a telling reminder of the transnational character of nostalgic longing and its imbrications with the media. Indeed, we could argue that the memory boom seen in the former socialist countries (and nostalgia as part of that) forms part and parcel of transnational, if not global trends. This is particularly clearly evident in the phenomenon of recycling of old media content, which is not limited to Eastern Europe but rather driven by increased commercial competition in the media sector globally, and the demand for cheaply produced media content capably of attracting high audience ratings. The same is probably true for at least some of the pleasures that people derive from revisiting socialist-era popular culture. As Alice Bardan argues, the sense of intimate, emotional connection and familiarity evoked by old media content is an important driver of postsocialist mediated memory, and has to be taken into account when seeking to explain the phenomenon. Rather than being an exclusive property of post-socialist societies, then, mediated nostalgia can be seen as a symptom of shared modes of engagement with the past characteristic of modern societies globally, inviting us to consider what, if anything, makes post-socialist nostalgia specific and distinct vis-à-vis other incarnations of mediated longing for the past.

While acknowledging transnational similarities and influences that span the East-West divide, we should of course not lose sight of regionally and nationally specific factors. Although systematic transnational comparison is beyond the scope of this themed issue, what emerges from the contributions is a set of aspects that merit considering when seeking to explain intra-regional variation. Most commonly considered are the political trajectories of individual countries since the end of communist rule, comprising the specific mode of exit 
from communism and the successive configurations of political power over time. These changes, for instance, help explain the changing attitudes to the re-broadcasting of socialistera entertainment in post-socialist Poland, as outlined in Szostak's contribution. The extent to which changes in political power structures affect mediated memory also depends, of course, on the nature of the media-politics relationship. As Kalinina shows in her article, Russian political elites, especially since Putin's rise to power, have exerted close control over the country's media, which means that the mediated representations of the Soviet past are closely aligned with ruling elites' attitudes.

Beyond the realm of politics, the extent to which the country's media are able to rely on sources of advertising revenue independent of state interference matters as well. From this perspective, it is instructive that even when the Polish authorities effectively erased socialistera programming from public broadcasting schedules, the same content quickly re-emerged through commercial broadcasters. As noted earlier, the need to make media content appealing to audiences, and at low cost, is a powerful incentive for re-using popular old content, whether it chimes with dominant political attitudes or not. In a similar manner, the effort to rebuild a sense of national belonging and pride can also exert considerable influence on mediated engagements with the socialist past, and can do so to some extent independent of political whims. This factor comes most clearly to the fore in the Russian case where the resurgence of positive representations of the Soviet past forms part of a broader effort to rekindle a sense of pride in being Russian. It is feasible to argue that elsewhere in the region, too, recent efforts to re-evaluate socialist-era culture as part of national cultural heritage - as for instance through the work of the National Audiovisual Institute in Poland - may likewise generate more positive attitudes to socialist media history.

Regardless of such economic, political and cultural factors that can explain the particular patterns of mediated post-socialist memory in individual countries, it is also important to understand and explain individual variation in mediated engagements with the past. As Szostak shows, generational cohorts constitute a powerful influence in this context; an individual's past trajectory of engagement with the media will to an extent depend on when that individual was born, and the generationally-specific experiences continue to play an important role in shaping individual attitudes to socialist media. Generational cohorts of course explain only a part of variation in individual remembering, and other demographic factors need to be considered, too. As visible in Russian materials examined by Huxtable, for instance, educational background and social position can play a role as well, as current attitudes to particular television programmes from the past can function as a sign of social distinction. It is feasible to expect that gender, political affiliation and other aspects of an individual's social position can also help explain the diversity of individual mnemonic practices and beliefs in each country.

Several contributions to the issue also emphasize the historical dimension of memory, and underscore the importance of understanding post-socialist media memories not only as a result of present exigencies, but also as an outcome of historical relationships and processes, be they global, national or personal in scope. As already noted, Szostak highlights the power of the past to shape the present in the realm of vernacular remembering, showing how memories of Polish television are shaped by generationally distinct patterns of historical experiences. Lundgren and Evans, on the other hand, show how the uneven remembering and forgetting of early achievements in global television can in part be seen as a result of the ways in which these achievements were produced historically. Related conclusions can be derived also from the contributions by Huxtable and Kalinina. These calls for an 
This is a pre-print version of the manuscript as accepted for publication in the European Journal of Cultural Studies 20(3), forthcoming June 2017

acknowledgment of the historical formation and layering of memory remind us that comparative thinking does not necessarily need to work transnationally, but can also be applied longitudinally, across time. It is only by combining both axis of comparison historically and transnationally - that we will be able to fully understand what makes the current articulations of post-socialist media memories truly post-socialist, in both senses: specific to the post-1989 context as opposed to arising from longer-term trends, and specific to former socialist countries as opposed to being part of global mnemonic developments.

\section{Acknowledgments}

This research was funded by The Leverhulme Trust (RPG-2013-025).

\section{References}

Apor, P. and Sarkisova, O. (eds.) (2008) Past for the Eyes: East European Representations of Communism in Cinema and Museums after 1989, Budapest: Central European University Press.

Assman, J. and Czaplicka, J. (1995) 'Collective Memory and Cultural Identity’, New German Critique 65: 125-133.

Bardan, A. (2012) 'Aftereffects of 1989: Corneliu Porumboiu’s 12:08 East of Bucharest', in A. Imre, ed., The Blackwell Companion to East European Cinema, New York: Blackwell, 2012, pp. 125-147.

Bernhard, M. and Kubik, J. (2014) Twenty Years after Communism: The Politics of Memory and Commemoration. Oxford: Oxford University Press.

Berdahl, D. (2010) On the Social Life of Postsocialism: Memory, Consumption, Germany. Bloomington and Indianapolis, IN: Indiana University Press.

Bloch, K (2013) 'The Life and Afterlife of a Socialist Media Friend: On the Lond-term Relevance of the Polish TV Series Czeterdziestolatek', VIEW - Journal of European Television History and Culture 2(3): 88-98.

Bodnar, J. (1992) Remaking America: Public Memory, Commemoration, and Patriotism in the Twentieth Century, Princeton, NJ: Princeton University Press.

Bourdon, J. (2003) Some Sense of Time: Remembering Television, History \& Memory 15 (2): 5-35.

Boyer, D. (2006) 'Ostalgie and the Politics of the Future in Eastern Germany', Public Culture 18(2): 361-81.

Boyer, D. (2010) 'From Algos to Autonomous: Nostalgic Eastern Europe as Post-imperial Mania', in Todorova, M. and Gille, Z. (eds) Post-communist Nostalgia, New York and Oxford: Berghahn Books, pp. 17-28. 
This is a pre-print version of the manuscript as accepted for publication in the European Journal of Cultural Studies 20(3), forthcoming June 2017

Boym, S. (2001) The Future of Nostalgia, New York: Basic Books.

Bracke, M.A. and Mark, J. (eds.) (2015) 'Between Decoonization and the Cold War: Transnational Activism and its Limits in Europe, 1950s-90s', special section of the Journal of Contemporary History 50(3).

Chari, S. and Verdery, K. (2009) 'Thinking between the Posts: Postcolonialism, Postsocialism, and Ethnography after the Cold War’, Comparative Studies in Society and History 51(1): 6-34.

Creeber, G. (2001) ““Taking Our Personal Lives Seriously”: Intimacy, Continuity and Memory in the Television Drama Serial', Media, Culture and Society 23(4): 439-455.

Daković, N. (2008) 'Out of the Past: Memory and Nostalgia in (Post-)Yugoslav Cinema', in P. Apor and O. Sarkisova (eds.) Past for the Eyes: East European Representations of Communism in Cinema and Museums after 1989, Budapest: Central European University Press, pp. 117-142.

Dayan, D. and Katz, E. (1992) Media Events: The Live Broadcasting of History. Cambridge, MA: Harvard University Press.

Dwyer, M. D. (2014) Back to the Fifties: Nostalgia, Hollywood Film, and Popular Music of the Seventies and Eighties, Oxford: Oxford University Press.

Frosh, P. (2011) 'Television and the Imagination of Memory: Life on Mars', in M. Neiger, O. Meyers, E. Zandberg (eds.) On Media Memory: Collective Memory in a New Media Age, Basingstoke: Palgrave Macmillan, pp. 117-31.

Godeano-Kenworthy, O. (2011) 'Deconstructing Ostalgia: The National Past between Commodity and Simulacrum in Wolfgang Becker’s Good Bye Lenin! (2003)’, Journal of European Studies 41(2) 161-177.

Holdsworth, A. (2011) Television, Memory and Nostalgia, Basingstoke: Palgrave.

Imre, A. (2013) 'Why Should We Study Socialist Commercials', VIEW - Journal of European Television History and Culture 2(3): 65-76.

Imre, A. (2016) TV Socialism. Durham, NC: Duke University Press.

Kapczynski, J. (2007) 'Negotiating Nostalgia: The GDR Past in Berlin in in Germany and Good Bye, Lenin!’, The Germanic Review: Literature, Culture, Theory 82(1): 78-100.

Keightley, E. and Pickering, M. and (2012) The Mnemonic Imagination: Remembering as Creative Practice. Basingstoke: Palgrave Macmillan.

Kaun, A. and Stirenstedt, F. (2012) Media Memories: The Case of Youth Radio DT64', Participations: Journal of Audience \& Reception Studies 9(2): 337-359.

Khinkulova, K. (2012) 'Hello, Lenin? Nostalgia on Post-soviet Television in Russia and Ukraine’, VIEW - Journal of European Television History and Culture 1(2): 94-104. 
This is a pre-print version of the manuscript as accepted for publication in the European Journal of Cultural Studies 20(3), forthcoming June 2017

Lepp, A. and Pantti, M. (2013) 'Window to the West: Memories of Watching Finnish Television in Estonia During the Soviet Period', VIEW - Journal of European Television History and Culture 2(3): 76-86.

Levy, D. and Sznaider, N. (2007) Memory Unbound: The Holocaust and the Formation of Cosmopolitan Memory’, European Journal of Social Theory 5(1): 87-106.

Li, H. and Lee, C.-C. (2013) 'Remembering Tiananmen and the Berlin Wall: The Elite U.S. Press’s Anniversary Journalism, 1999-2009’, Memory, Culture \& Society 35(7); 830-846,

Lizardi, R. (2014) Mediated Nostalgia: Individual Memory in Contemporary Mass Media, Lanham: Lexington Books.

Mälksoo, M. (2014) ‘Criminalizing Communism: Transnational Mnemopolitics in Europe’, International Political Sociology 8: 82-99.

Mark, J. (2010) The Unfinished Revolution: Making Sense of the Communist Past in CentralEastern Europe, New Haven, CT: Yale University Press.

Mihelj, S. (2014) 'The Persistence of the Past: Memory, Generational Cohorts and the "Iron Curtain”, Contemporary European History 23(3): 447-468.

Mikula, M. (2003) 'Virtual Landscapes of Memory', Information, Communication \& Society 6(3): 169-186.

Misztal, B.A. (2010) 'Collective Memory in a Global Age: Learning How and What to Remember,' Current Sociology 58(1): 24-44.

Nadkarni, M. and Shevchenko, O. (2004) 'The Politics of Nostalgia: A Case for Comparative Analysis of Post-Socialist Practices’, Ab Imperio 2 (2004): 487-519.

Niemeyer, K., ed. (2014) Media and Nostalgia: Yearning for the Past, Present and Future. Basingstoke: Palgrave.

Norris, S. M. (2012) Blockbuster history in the new Russia: Movies, memory, and patriotism. Bloomington, IN: Indiana University Press.

Petrović, T. (2009) 'Becoming Real Men in Socialist Yugoslavia: Photographic Representations of the Yugoslav People's Army Soldiers and Their Memories of the Army Service', CAS Sofia Working Paper Series 2 (2009): 3-17. Accessed at www.ceeol.com, 10 July 2015.

Pobłocki, K. (2008) 'The Economics of Nostalgia: Socialist Films and Capitalist Commodities in Contemporary Poland', in P. Apor and O. Sarkisova (eds.) Past for the Eyes: East European Representations of Communism in Cinema and Museums after 1989, Budapest: Central European University Press, pp. 181-212.

Rabikowska, M. (2013) The Everyday of Memory: Between Communism and PostCommunism, Bern: Peter Lang. 
This is a pre-print version of the manuscript as accepted for publication in the European Journal of Cultural Studies 20(3), forthcoming June 2017

Reifová, I. (2009) 'Rerunning and "Re-watching” Socialist TV Drama Serials: Post-Socialist Czech Television Audiences between Commodification and Reclaiming the Past', Critical Studies in Television 4 (2): 53-7.

Reifová, I., Gillárová, K. and Hladík, R. (2012) 'The Way We Applauded: Hoe Popular Culture Stimulates Collective Memory of the Socialist Past in Czechoslovakia: The Case Study of the Television Serial Vyprávěj and its Viewers', in Imre, A., Havens, T. and Lustyik, K. (eds.) Popular Television in Eastern Europe During and Since Socialism, London: Routledge, pp. 199-221.

Rutten, E., Fedor, J. and Zvereva, V. (eds.) (2013) Memory, Conflict and New Media: Web Wars in Post-Socialist States. London: Routledge.

Said, E. (1978) Orientalism, New York: Pantheon.

Sarkisova, O. and Shevchenko, O. (2014) 'Soviet Past and Domestic Photography: Events, Evidence, Erasure’, in Shevchenko, O. (ed.) Double Exposure: Memory and Photography, New Brunswick, NJ: Transaction Publishers, pp. 147-176.

Sonnevend, J. (2016) Stories without Borders: The Berlin Wall and the Making of a Global Iconic Event. Oxford: Oxford University Press.

Sorescu-Marinković, A. (2012) 'The World Through the TV Screen: Everyday Life under Communism on the Western Romanian Border', Martor: The Museum of the Romanian Peasant Anthropology Review 17: 173-88.

Tileaga, C. (2012) 'Communism in Retrospect: The rhetoric of historical representation and writing the collective memory of recent past’, Memory Studies 5(4) 462-478.

Todorova, M. and Gille, Z. (ed.) (2010) Post-communist Nostalgia, New York and Oxford: Berghahn Books.

Tzanelli, R. (2011) Cosmopolitan Memory in Europe's Backwaters. London and New York: Routledge.

Velikonja, M. (2009) 'Lost in Transition: Nostalgia for Socialism in Post-socialist Countries', East European Politics \& Societies 23(4): 535-551.

von der Goltz, A. (2013) ‘Making Sense of East Germany’s 1968: Multiple Trajectories and Contrasting Memories’, Memory Studies 6(1): 53-69. 